\title{
Using Social Media As Historical Marketing Tool For Heritage Sites In Eastern New York State
}

Dr. Michael S. Pepe, Siena College, USA

Rachel Bournique, Siena College, USA

\begin{abstract}
Heritage tourism marketing has been studied around the globe with many different areas offocus. This study examines heritage site marketing techniques in New York State and uses three research objectives: (1) to determine what marketing techniques are currently being used by heritage sites (2) examine how the heritage sites use social media and (3) determine social media best practices for heritage sites and recommendations for improvement. Findings show that New York State heritage sites primary use word of mouth marketing, relationship marketing, and emarketing. Social media is used to communicate mostly with adults and seniors but do not focus heavily on millennials which is a major issue as identified in the study. Finally, the preferred social media platforms used by heritage sites are websites and Facebook, which are effective tools for visitor engagement, marketing events, programs and exhibits, and attracting new visitors.
\end{abstract}

Keywords: Heritage Sites; Social Media; Historical Marketing; Museum Marketing

\section{INTRODUCTION}

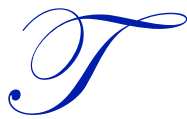

his study analyzes the use of social media for heritage sites in Eastern New York State. Heritage sites include battlefields and forts, history museums, historical societies and historic houses. The expression used to describe the "business and practice of attracting and accommodating visitors" to these heritage sites is heritage tourism (Advisory Council on Historical Preservation, 2014).

Most, if not all, the heritage sites in New York State have a similar mission which is to preserve, celebrate, and share the history of New York. In order for heritage sites to carry out their mission of preservation and education they must have a consumer base to educate and attract to each location. While some heritage sites attract visitors from across the nation others have a very small reach limited to their local community. Either way, heritage sites must rely on marketing activities to build relationships with consumers. Marketing activities are becoming more integrated into the areas of public history, museum studies, and heritage tourism to enhance the long term success of each.

The conversation linking marketing and heritage tourism began in the 1960's and has since evolved into a field with professionals, different areas of study, and large amounts of literature. Both fields recognized that marketing did exist in heritage tourism, but there was very little written down about this connection. Although Richard Foster noted that museums, or heritage sites, were aware that strategic marketing was important in 1979, it took another decade for professionals to begin looking more carefully at how to combine these two fields most effectively into heritage tourism marketing, more commonly referred to as "museum marketing" (Foster, 1988).

The late 1980's and the 1990's were evolving decades for heritage tourism as marketing theories were applied to heritage tourism (Foster, 1992). The problem was this often was a one-way conversation with marketing strategies and techniques being placed into the script of heritage tourism management.

This one way conversation transformed into a two way dialogue in the 1990's. Fiona McLean and Hugh Bradford were two of the first individuals to incorporate strategic marketing to heritage tourism in a way that heritage sites could understand, use, and apply (McLean, 1993). A new trend in research focused on marketing and how the visitor 
experienced heritage sites (Yucelt, 2000). Based on these new studies, site administrators began to recognize the importance of marketing to satisfy the newly identified needs of the public. The studies published about visitor's motivations and wants allowed administrators at the heritage sites to begin examining their marketing efforts for effectiveness in reaching their public.

In light of this ability to more closely examine the effectiveness of marketing strategies, heritage tourism marketing literature published in the early 21 st century has been more focused on specific aspects of marketing including branding, e-marketing, social media, word of mouth marketing, and relationship marketing (Caldwell, 2000). Social media marketing has been receiving a growing amount of attention in the past few years as it has been increasingly incorporated into the public's daily lives. People in all fields related to heritage tourism are realizing the growing relevance of social media (Ackerson, 2011).

Since 1993, there have been a variety of different studies done about heritage tourism, marketing, and most recently social media as applied to both of these. However, little research has been done about smaller museums here in America, and even less has been published about historical heritage sites specifically. The studies that have been published are most commonly about art museums or larger museums in general (Marcketti \& Fiore. 2012). Finally, there has been a variety of different studies done about marketing, social media, and museums in places other than New York State, including the Midwestern United States, Virginia, England, Turkey, Scotland, and Canada. (Bradford, 2011).

\section{CURRENT STATE OF HERITAGE TOURISM IN NEW YORK STATE}

New York State has a rich history of heritage tourism dating back to 1836 with the establishment of the State Geological and Natural History Survey, now known as the New York State Museum. Within New York there are many institutions that are designed to administer to historic sites across the state. These include: (1) NYS Office of Parks and Historic Preservation, which oversees state owned parks, historic sites, and heritage areas (2) NYS Council on the Arts which supports the preservation and expansion of cultural and heritage organizations (3) Museum Association of New York, a state-wide advocacy resource for all heritage organizations, and (4) New York State Historical Association, a private organization dedicated to preservation and education.

Unlike in any other state, museums are chartered by the New York State Department of Education and the Board of Regents. To hold heritage sites to a high standard of education and organization there are two levels of charters a site can receive. First a heritage site receives a provincial charter for three to five years in which they are expected to meet the standards set by the Board of Regents. After the five year period, sites can either apply for their charter to be extended, or they can apply for an absolute charter. Sites with absolute charters meet the standards set by the Regents including, "financial stability, programmatic accomplishment, and a well-founded reputation for excellence" (http://www.nysm.nysed.gov/charter/).

As mentioned above, there are a variety of administrative bodies that deal with heritage sites, but unfortunately there are very few institutions that support heritage sites financially. For large projects heritage sites can apply for grants from national organizations such as the National Endowment for the Humanities, but the New York State Council on the Arts is the only state agency that provides funding to museums. However, these funding opportunities are very competitive, grant writing is time consuming, and the financial funds are limited. In light of the economic recession that began in 2007, it is not surprising that the New York State Council on the Art's budget began to be cut. Between 2005 and 2011, NYSCA's annual budget had been reduced by 40\% (Baldwin, 2011).

According to a 2012 national survey taken by the American Association of Museums, $70 \%$ of museums reported being in "economic stress." The Museum Association of New York describes the current state of the NYS museums as "living on the knife's edge" (Status of NYS Museums, 2014). MANY's 2011 survey of the status of New York State museums highlights the difficulties faced by museums after the economic recession. Museums are turning to unconventional methods to try and fulfil their missions including collaboration with other non-profits and For-profit business alike, seeking out new ways of communication such as social media, and even reducing programming (Baldwin, 2011). Without financial support from the State, museums must find new ways to fund their continued existence. 
One of these ways is to reassess and reinvest in marketing efforts. Marketing involves "monitoring and shaping how a museum presents itself to the public, in terms of advertising, press, product development, wayfinding and promotional signage, and more, while also trying to maintain and attract more visitors, members, and prospective funders "(Stevens \& Luke, 2011). Over the past 30 years marketing has become recognized as a crucial element of heritage site management. As noted in the preceding literature review, there are many publications that integrate heritage tourism and marketing. In New York State, initiatives such as the "I Love NY" campaign and especially the Path through History initiative have each encouraged heritage tourism marketing. "I Love NY" has been an existing campaign by the NYS Department of Economic Development encouraging tourism throughout the state in areas such as Sports \& Gaming, Nature, Food \& Drink, Arts \& Culture and History (New York Hotels, 2014).

\section{RESEARCH OBJECTIVES AND METHODOLOGY}

This study fills in some of the gaps in the literature discussed above by researching a variety of different heritage sites in New York State and how they market their resources by primarily focusing on social media. Based on the previously stated gap in existing literature, a survey was developed to achieve three specific research goals:

1. Determine what marketing techniques are being used by heritage sites

2. Determine how heritage sites use social media

3. Determine social media best practices for heritage sites and recommendations for improvement

A survey was developed consisting of four parts with a possible total of 24 questions and was designed based on previous research about survey development, the literature review and primarily to achieve the research objectives. Parts I and II consisted of 10 general heritage site and marketing questions. The purpose of these particular sections was to characterize the type of heritage site the respondent was from (type of site, staff numbers, annual budget, most common visitors) and to understand current marketing efforts (hours spent marketing, existence of marketing plan, target audiences, effectiveness of marketing techniques).

Parts III and IV consisted of the bulk of the survey. The goals of these sections were to understand how heritage sites used social media (what forms, how long, who is responsible for updating them, and what audiences are targeting using social media) and how effective social media is for a variety of different marketing tasks such as engaging with visitors before, after, and during the heritage site visit, marketing events and venue rentals, attracting new visitors, and fundraising. For these questions in Part IV semantic differential scales were used for respondents to rate the different forms of social media from very ineffective to very effective.

\section{Survey Participants}

Qualtrics software was used to develop and distribute the survey to 165 heritage sites in eastern New York. The population included a variety of history museums, multiple historic forts and battlefields, historical societies that run a museum, historical societies that do not run a museum and historic houses. The geographical location of the heritage sites were within 100 miles of Albany, NY and was selected to narrow the research to eastern New York State around the capital region. Figure 1 below identifies the geographical location of the heritage sites used in the study. 


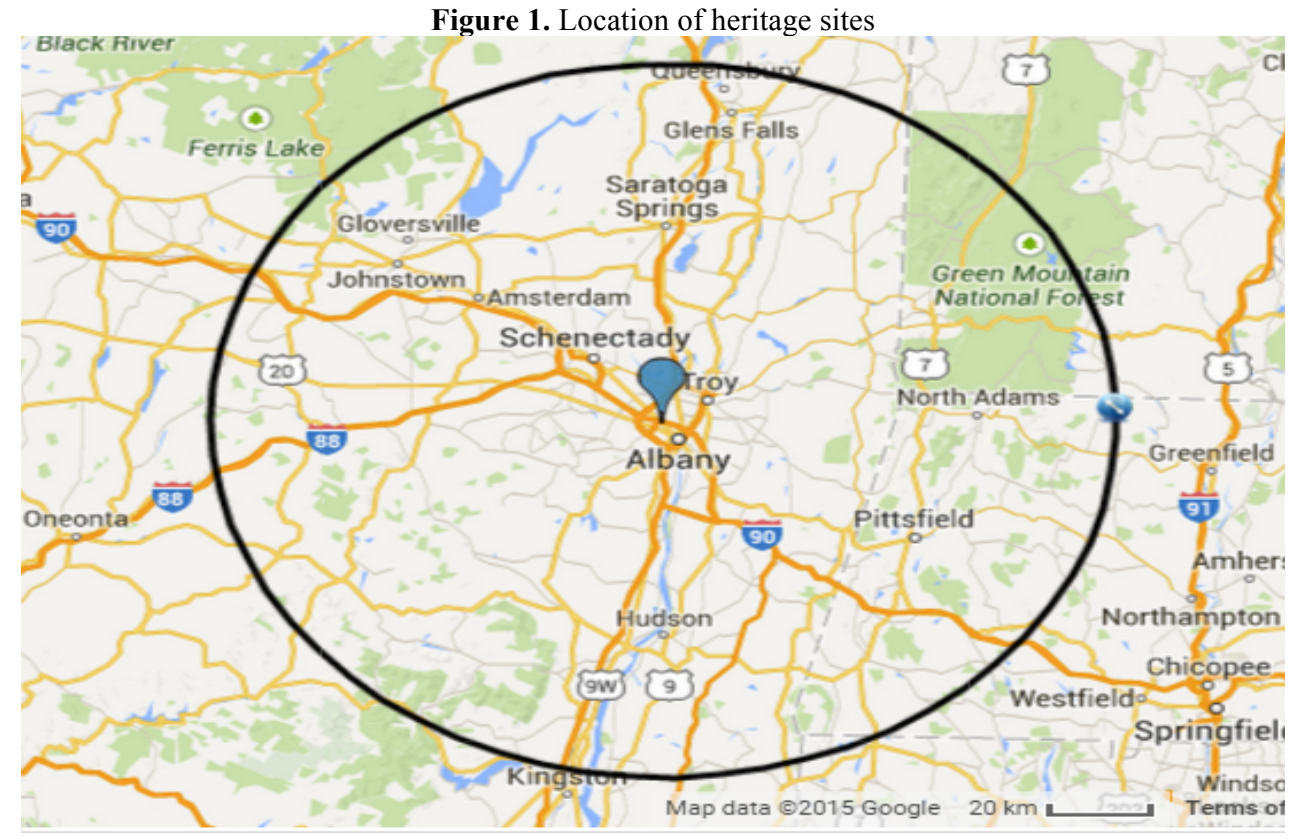

The web search delivered a total of 203 heritage sites all of whom were contacted via phone or email. Thirty eight heritage sites were unable to be contacted or requested to not be included in the project which resulted in the 165 heritage sites to whom the survey was delivered.

The survey was completed by a total of 53 participants, giving a 32\% response rate. The majority of the sites surveyed were historical societies and historic houses $(n=39)$. Of the heritage sites $89 \%(n=34)$ have 5 or less full time staff. Only two outliers had more than 30 people on their full time staff. This information is contained in Table 1 and Figure 2 below.

Table 1. Types of Heritage Sites

\begin{tabular}{l|c|c}
\hline & Number & Percentage \\
\hline Historic Building & 16 & $30 \%$ \\
\hline Historical Society with Museum & 15 & $28 \%$ \\
\hline Historical Society with no Museum & 11 & $20 \%$ \\
\hline Historic Museum & 10 & $18 \%$ \\
\hline Other & 5 & $9 \%$ \\
\hline
\end{tabular}

Figure 2. Number of Full Time Staff

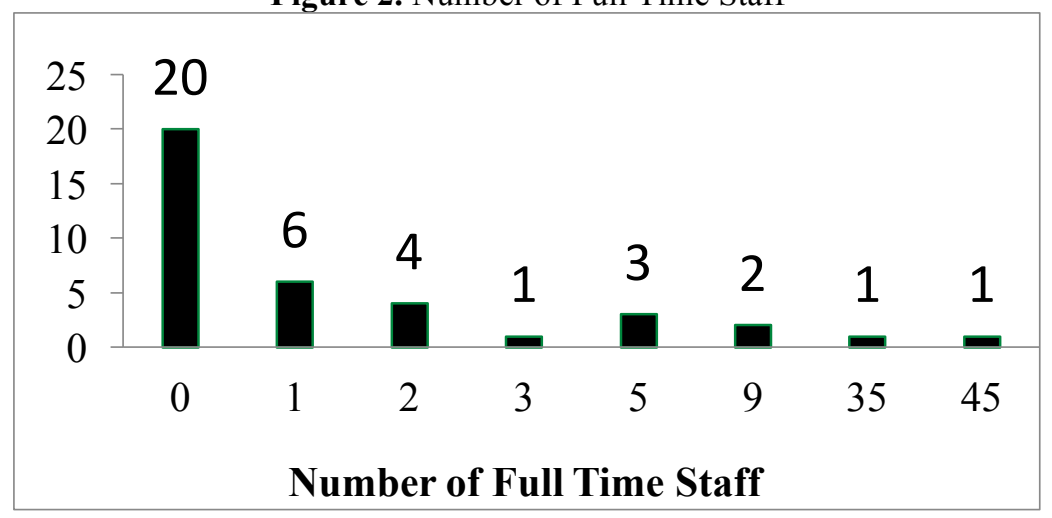


The 53 sites were also asked to identify their top visitor groups. Adults $(\mathrm{n}=24)$ and seniors $(\mathrm{n}=30)$ were identified as either the top visitor group or the second most common visitor group as shown in Figure 3.

Figure 3. Visitor Group by Age

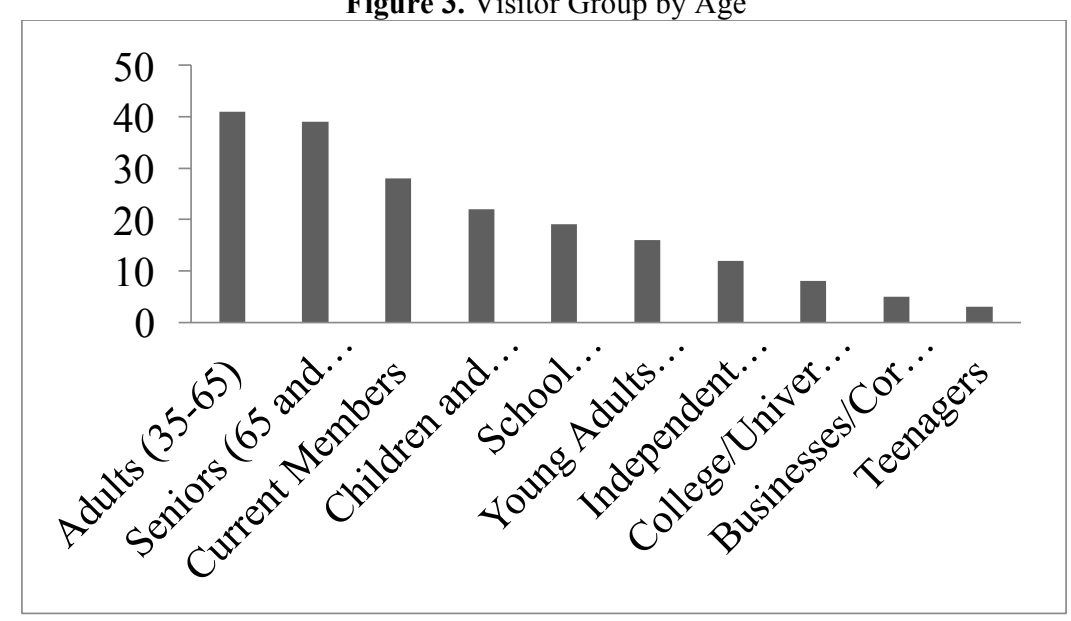

The data indicates that the large majority of the surveyed population are small heritage sites, mainly historical societies, with very few, if any, full time staff who market to older adults.

\section{Research Objective I: Marketing in Heritage Sites}

The first research objective of this study was to determine what marketing techniques are being used by heritage sites. To determine how the heritage sites market themselves, the survey asked questions about staff, time, and techniques.

The rise in visitor-studies and literature about heritage tourism marketing has made it possible for heritage sites to research and create strategic marketing plans. Effective marketing strategies and efforts can help heritage sites fulfil their missions of preservation and education (Kirezli, 2003). Large heritage sites, such as the New York State Museum or the Albany Institute of History and Art, have marketing associates on staff while marketing activities at the smaller organizations, which include the majority of the surveyed population, are taken on by other members of the heritage site team, such as the director, president, curator, or volunteer (New York State Museum, 2014).

As most of the marketing activities at the surveyed sites are not completed by people with a marketing background it is not surprising to find that only 10 of the 53 sites surveyed have a marketing plan. Similarly, very little time each week is spent on specific marketing efforts. Only nine sites indicated they spend more than five hours on marketing each week and the majority of sites spend one hour or less on marketing each week. This information is contained in Figure 4.

Figure 4. Hours Spent on Marketing Activities per week

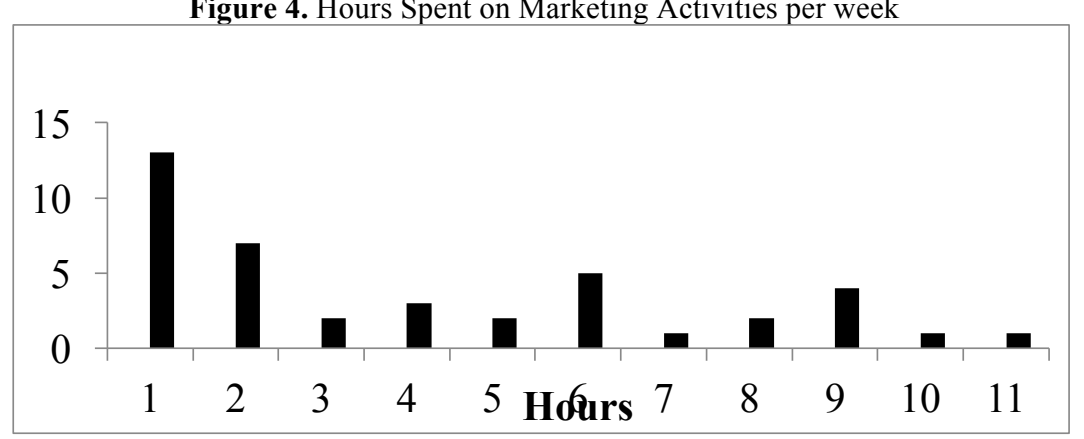


The heritage sites in New York were also asked to identify the focus of their marketing efforts. Figure 5 identifies the top four visitor groups that were also rated as the top targeted audiences for marketing strategies are adults (ages 3565 ), seniors (ages 65 and older), current members of the heritage site, and children and families.

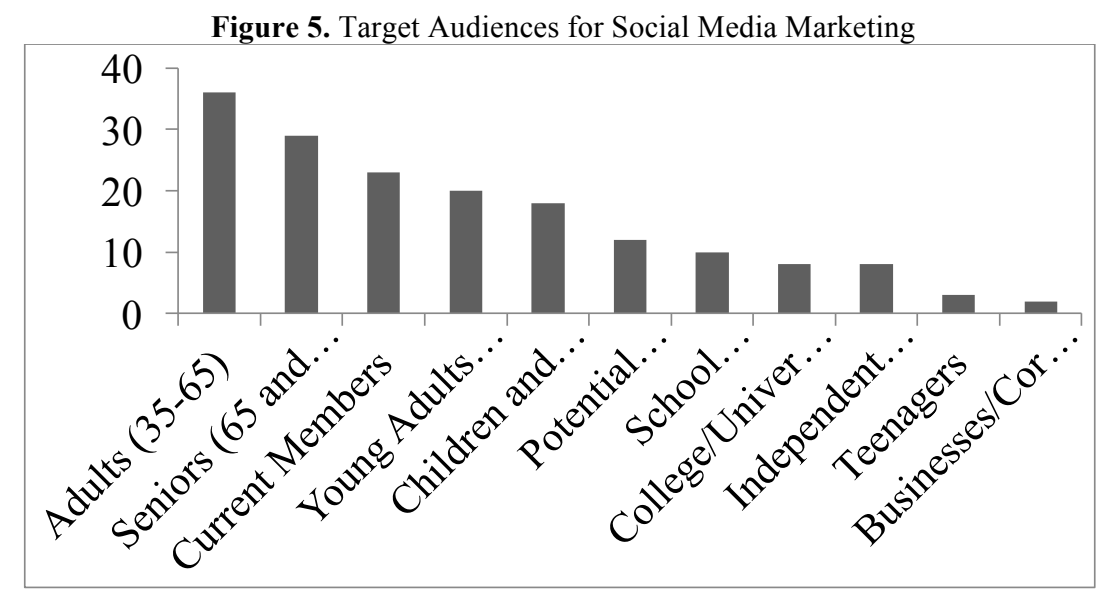

Why were adults and seniors ranked the top two marketed groups? The top two sources of funding, as idenified by the survey respondents, are memberships $(\mathrm{n}=18)$ and state and national funding $(\mathrm{n}=11)$. Marketing is especially important for recruiting memberships and it is evident that the heritage sites are marketing primarily to adults and senior citizens who have potential to become members.

Representatives from the sites were able to rate a variety of marketing techniques for effectiveness. The top three marketing techniques, as portrayed in Table 2, that had the highest mean of effectiveness are word-of-mouth marketing, print marketing (including fliers, pamphlets and posters), and e-marketing (including use of social media and a website).

Table 2. Effectiveness of Marketing Techniques

\begin{tabular}{l|c}
\hline \multicolumn{1}{c}{ Effective Marketing Techniques } & $\begin{array}{c}\text { Mean of Effectiveness. Scale: } \\
\text { (Very Ineffective) - 5 (Very Effective) }\end{array}$ \\
\hline Word of Mouth & 4.26 \\
\hline Website & 3.9 \\
\hline Social Media & 3.78 \\
\hline Posters & 3.73 \\
\hline Fliers/Pamphlets & 3.73 \\
\hline E-Newsletters & 3.61 \\
\hline Collaboration & 3.54 \\
\hline Experience Branding & 3.35 \\
\hline Information Branding & 3.32 \\
\hline Relationship Marketing & 3.26 \\
\hline Radio Commercials & 3.21 \\
\hline
\end{tabular}

\section{Word of Mouth Marketing}

Word-of-mouth marketing has been identified as one of the most effective marketing techniques for heritage tourism by scholars and surveyed heritage sites alike. Word-of-mouth marketing occurs when people promote the heritage site by communicating with others and this can create an exponential growth in the dissemination of information. One of the reasons word-of-mouth is especially advantageous for heritgate sites is because of the lack of cost and the availabily of people. Anyone who attends an event or a progra hosted by the heritage site has potential to become a 
word-of-mouth marketer for the site. Staff members, trustees, and volunteers are also important word-of-mouth marketers. The heritage site is responsible for ensuring that the messages spread through word-of-mouth are positive and true to their site, which often worries marketers due to the lack of control that comes with word-of-mouth marketing (Miller \& Lamas, 2010).

In order to make certain the heritage site is being represented properly reliance is needed on branding and relationship marketing. Even though these two strategies were not ranked as very effective by the survey they are important strategies for enhancing word-of-mouth marketing. Branding is defined as developing an identity that makes the heritage site appealing and reputable to both visitors and other insitutions (Lumb et.al., 2009). A heritage site's brand, what the public associates with the site, could either be focused on the subject of the site or the desitination at which the site is located (Caldwell, 2010).

Word-of-mouth marketing relies on the public to share their impressions and experiences with the heritage site. Heritage sites can influence their brand by studying what their visitors think of their experience through surveys and by receiving and responding to feedback.

Social media can be an effective tool for studying, developing, and sharing a heritage site's brand. Public reactions to different products, ideas, or services can be monitored on social media by studying how many "likes," "shares" or "retweets" a post about the product, idea, or service receives. Heritage sites can also receive real-time feedback through social media, especially on Facebook and Twitter (Miller \& Lamas, 2010).

While branding speaks to the message spread by word-of-mouth marketing, relationship marketing speaks to the people who are spreading this message. As previously mentioned, trustees and staff are two important groups of people for word-of-mouth marketing. Relationship marketing describes the efforts of the heritage site to create long term relationships with visitors and funding or collaborative organizations (Miller \& Lamas, 2010).Visitors with whom heritage sites form trusting and loyal relationships with are more likely to return to the site and are more likely to recommend the site to other people. Some visitors may purchase memberships, which also can help the heritage site maintain a relationship. Members and frequent visitors will know about the heritage sites programs and services and can thus knowledgably spread the word about the site.

Because heritage sites cannot fulfill the needs of every type of audience, site administrators must choose specific audience groups to target their marketing efforts (Kotler et.al., 2008). As indicated above, the heritage sites surveyed target adults and seniors as they are the primary purchasers of memberships - a main source of funding for the heritage sites. Social media, especially Facebook, allows administrators to share posts with specific audiences. Facebook also provides users with audience demographic information, such as what type (age, gender) of people "like" posts. Using this information, heritage sites can adapt their message to fit the audiences of their differnet marketing venues.

Social media is also an effective tool for relationship marketing because it allows for communication between the heritage site and its public (Bartak, 2007). This communication can take place both before, during, and after the onsite visit. This before and after communication is made possible and enhanced by social media. Websites allow visitors to gather information about what to expect during their visit and social networking sites, such as Facebook and Twitter, and email gives visitors a chance to "stay in touch" with the heritage site after their visit. Heritage sites can communicate with their audiences on a more personal level using social media, both by responding to comments on posts and answering emails. Social media has given heritage sites the opporutnity to continue relationships with visitors even after their on-site visit, an advantage that previously would have required printing and sending newsletters.

Social media is clearly an effective tool for word-of-mouth marketing as it can be used for both branding and relationship marketing. Scholars also identify social media as a "facilitator" for word-of-mouth marketing because of the reach and speed of different social networking sites (Fletcher \& Lee, 2012). With social media's broad scope, heritage sites can reach audiences who may not otherwise be aware of the site. This can include international audiences or simply people in another state (Trends Watch, 2012). 


\section{Print Marketing}

Print marketing has been the traditional mode for advertising and promoting heritage sites in the past. Print marketing includes posters, signs, pamphlets, guidebooks, brochures, newspapers and newsletters. Although there are many different options associated with print marketing, the options are very static forms of marketing. Brochures, advertisements, signs, and pamphlets have restricted amounts of space and therefore can only provide a selected amount of information about the heritage site (Chiou, 2008). Another limitation to print marketing is cost. Advertisements in newspapers, printing brochures, pamphlets or signs, and purchasing space in a magazine or guidebook can be expensive projects for small heritage sites.

As the internet has risen in popularity and usage, print marketing has become more and more obsolete. Twenty-first century audiences are looking for general information about the heritage site and its offerings, information that used to be in print media, online - especially on websites (Chiou et. al., 2008).

\section{E-Marketing}

Using the internet for marketing purposes is refered to as "e-marketing." E-markeitng includes e-mails, e-newsletters, information on collections/exhibits/programs posted on websites, ineractive websites, user-generated content online, volunteer recruitment, donation or sponsorhip oportunities, ticket promotions, venue rental opportunities, and the use of social media (Liew \& Loh, 2007).

The main platforms for e-marketing are websites and social media. Websites can be used for listing general information but can also provide "a venue for learning, exploration, and repeated visitor-ship" (Lindsay, 2013). Websites also provide opportunities to sign up for memberships, e-newsletters, rent facilities, or even purchase sponsorships and memberships (Liew \& Loh, 2007). All of these bring in revenue for the heritage site while also communicating and engaging with audiences.

\section{Research Objective II: Social Media Use}

Scholars recognize social media's growing importance for engaging with visitors and is one of the most influential ways that enhances marketing efforts. Another reason why social media is an important tool for heritage sites is because of the low monetary cost. Most social networking sites require no monetary payment and the cost of website domains varies, but can be reduced depending on how it is acquired. Many participants of the survey used in this study stated that low cost was one of the many advantages of using social media.

Although social media has traditionally been associated with teenagers and young adults, the heritage sites surveyed named adults and seniors as the primary audiences targeted using social media. Current members and young adults were rated the third and fourth top marketing groups.

At half of the sites surveyed either the president, director or a volunteer is primarily responsible for updating social media sites. Figure 6 shows the frequency of social media updates. The types of social media that are used most frequently by the heirtiage sites are Facebook, websites, and Twitter. 54\% of respondants use Facebook mulitple times per week and less than $1 \%$ do not use Facebook at all. Personal websites are primarly updated 3 or less times per month but few heritage sites (12\%) use it on a daily basis. Twenty heritage sites use a page on another organization's website (such as the New York State Park and Recreation's website). Less than half of these heirtage sites use this page more than once a month. Finally, Twitter and Instagram - social media platforms that are primary used as "apps" on smartphones or tablets are only used by 18 sites. Twitter is used multiple times per week by seven of these sites and Instagram is only used multiple times per week by two sites. 
Figure 6. Frequency of Social Media Updates

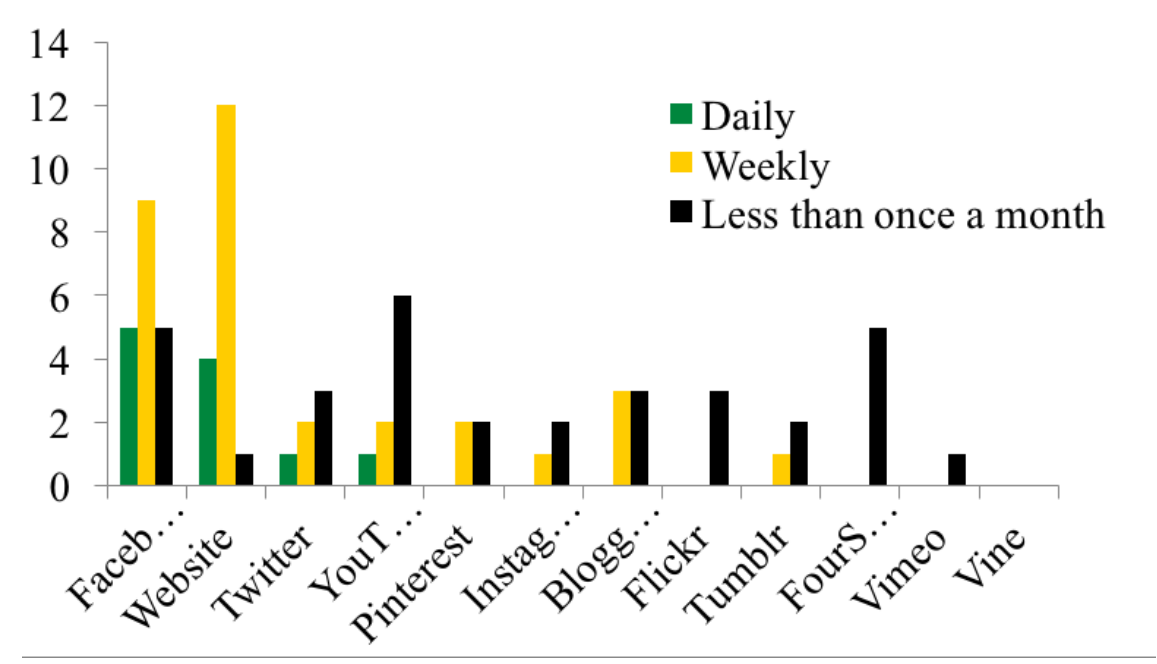

\section{Research Objective III: Determine Social Media Best Practices for Heritage Sites and Recommendations for Improvement}

The final research objective was to determine how social media can be an effective marketing tool. In the survey, participants were asked to rate different forms of social media for effectiveness. The following discussion will examine three different marketing activities and what types of social media were rated effective tools by the survey participants.

\section{Visitor Engagement}

Engaging with visitors is crucial to relationship and word-of-mouth marketing. Heritage sites should engage with their visitors before, after, and during their on-site visit. It should be noted, however, that not every heritage site has a location for audiences to visit. Some, such as historical societies, only host programs and offer services in different venues as they do not have a space - such as a historic house or a museum - for audiences to visit. For these types of heritage sites, engagement with visitors may be especially difficult as they cannot rely on regular foot-traffic. For these historical societies, and for all other types of heritage sites, social media can be a very effective tool for visitor engagement.

Websites and Facebook were found to be the most effective types of social media for engaging with visitors before and after the heritage site visit as both allow for personalized communication with visitors. Although websites are usually the "go-to" tool for anyone interested in attending a museum (look for hours, directions, exhibit listings), Facebook can be used for real-time communication with large audiences. Audience members can "like," comment on, and "share" postings and pictures. Heritage sites can update their websites and social networking sites regularly and share with their visitors what is happening at the site. A few heritage sites in New York have found Facebook to be an effective tool for keeping audiences updated on construction or renovation projects, allowing engagement during times when visitors could not actually visit the site.

The other social media platforms that were rated as effective for engaging with visitors before and after their on-site visit were Twitter (19\% rated it effective), YouTube (12\%), Pinterest (9\%) and Instagram, Flickr, and Blogging (each $6 \%$.

As with engaging with visitors before and after their on-site visit, websites and Facebook were found to be effective tools for visitor engagement during on-site visits. However, while the majority rated each "effective" for before/after site visit engagement, the majority of people noted that they do not use social media for engaging with visitors during 
site visits. This leads to the conclusion that the participating heritage sites do not use social media for "internal marketing" - marketing to audience while they are at the heritage site.

\section{Marketing Events, Programs, Exhibits}

When asked how effective social media is for marketing events, programs and exhibits participants responded very similarly as when asked about engaging with visitors. About $80 \%$ of respondents rated websites and Facebook as effective tools. Eight respondents also rated Twitter to be an effective tool for marketing events, programs and exhibits. Personal websites are effective tools for marketing events because it is easy to list information about products and services on a webpage. Facebook can be effective because of its extensive reach as audiences can share heritage sites postings about events, programs and exhibits extending their reach even farther.

\section{Attracting New Visitors}

Once again, websites and Facebook were named effective social media platforms for attracting new visitors. This marketing activity corresponds very closely with engaging with visitors before their on-site visit. If heritage sites can engage with the potential visitor in a positive manner, an on-site visit will be more likely to happen. Websites and Facebook differ from Twitter (rated by eight people to be effective) because people who visit these platforms can immediately view information about the site. Pictures are often posted on these two platforms showcasing exhibits, programs, or people enjoying their visit. Potential visitors can also visit a website or Facebook to find out where the site is located and what hours the site is open to the public.

\section{CONCLUSIONS AND RECOMMENDATIONS}

Based on the literature review and results of the survey, social media is growing in use and importance for heritage sites. Websites and Facebook are currently being used by heritage sites and these two are found to be the most effective types of social media. Heritage sites are using social media because it is inexpensive, it allows for greater communication with visitors, and it has a larger reach than traditional marketing.

Successful marketing with social media does come with challenges. According to the survey the main reasons why heritage sites do not use social media is because of the lack of resources - especially staff, time, and knowledge. Scholars recognize that quality of content, relevant activity, and timely activity are necessary for successful social media marketing. Without sufficient time or staffing it would be difficult for a heritage site to keep a regulated and consistent posting schedule. Time is required to update content on websites, to create postings for social networking sites, and even for staff to learn how to use the different types of social media. Therefore, it is not adequate to say that social media is a fool proof marketing tool for every heritage site in New York, but it can be said that heritage sites have found it to be an effective tool for a number of different marketing strategies.

For heritage sites that do not currently use social media, it would be prudent to discuss the idea with volunteers. If anyone is willing to put in the time, it would be recommended that the heritage site invest this time in social media marketing. For heritage sites that already use social media and are looking to expand their usage, it would be recommended that they concentrate on developing what they already have rather than trying out any new platforms. There was a positive correlation found in the survey between hours spent updating social media and how effective social media is for marketing purposes. This means that the more hours spent updating the social media, the more effective it is. For this reason, it would be recommended that more time be spent on updating the current forms of social media than spending less time on multiple different platforms.

Like many things in life, social media requires time and effort to be effective. However, when time and effort are put into social media marketing it is found to be an effective tool for heritage sites. New York State has a rich history and this history is being preserved and presented at hundreds, if not thousands, of heritage sites throughout the state. Unfortunately many of these heritage sites are small, understaffed locations without large audiences to share this history with. For these small heritage sites, social media can be an inexpensive tool to use to market their resources whether that be collections to be seen in a museum setting, an event that can be attended, or a workshop to be educated at. Social media allows small heritage sites to have a voice and gives them the opportunity to make a once small voice 
grow louder. Although it certainly won't solve every problem a heritage site may face, social media can be a useful tool for sharing New York's history with the greater public.

Based on the findings from this study it is evident that heritage sites need to target millennials more through their social media efforts as this generational cohort will be important for long-term success. Engaging with millennials through social media and designing marketing programs aimed at increasing their interest and visit to heritage sites is highly recommended.

Social media needs to be an essential component of the activities of heritage sites and should be allocated sufficient resources instead of being relegated to ancillary tasks of those responsible for their implementation. Also, heritage sites need to monitor social media trends and use by consumers, particularly among millennials, to ensure the most effective methods are utilized to reach consumers. A further expansion of digital marketing techniques is recommended through the use of search engine marketing, Google AdWords and analytics.

\section{AUTHOR BIOGRAPHIES}

Dr. Michael S. Pepe is an associate professor of marketing at Siena College. Dr. Pepe's teaching interests pertain to international marketing, marketing pedagogy, and marketing metrics. An integral component of Dr. Pepe's teaching methodology is application of all concepts that were developed during his 19 years of professional marketing experience. Michael is the first recipient in the Siena College School of Business to have received the Teaching, Research and Service Excellence awards. He has published in the Journal of Product and Brand Management, Journal of Marketing Management, Journal of Business Case Studies and the Journal of Business and Economics Research. Rachel Bournique. E-mail: mpepe@siena.edu

Rachel Bournique is a 2015 graduate of Siena College with a major in history. Rachel was a members of the Honors Program at Siena and is a member of the Museum Association of New York. Rachel studied at the McCormick Center for the study of the American Revolution and has presented her research at academic conferences.

\section{REFERENCES}

Ackerson, A. (2011), “The History Museum in New York State: A Growing Sector based on Scarcity Thinking, 'The Public Historian, 33(3), 18-37.

Addison, E. (1993), "Museum Marketing: A Tool for Survival." Muse/Canadian Museums, 11(2), 2-4.

Advisory Council on Historic Preservation, "Defining Heritage Tourism," Partnering to Promote Heritage Tourism in Local Communities: Guidance for Federal Agencies, March 3, 2006; http://www.achp.gov/ht/ defining.html

Albany Institute of History and Art, "Contact," Albany Institute of History and Art, http://www.albanyinstitute.org/ contact.html (accessed July 18, 2014).

Baldwin, J. (2011). “The State of New York's Museums 2011-Your Home For History” http://download.aaslh.org/ AASLH-Website-Resources/The+State+of+New+Yorks+Museums+2011.pdf

Bartak, A. (2007) "The Departing Train: Online Museum Marketing in the Age of Engagement," In Museum Marketing: Competing in the Global Marketplace, edited by Ruth Rentschler and Anne-Marie Hede, 21-37, Oxford, UK: Elsevier.

Bradford, Hugh. (1991). "A New Framework for Museum Marketing." In The Museums Profession: International and External Relations, edited by G. Kavanagh, 85-98, Leicester: Leicester University Press.

Bryant, J. (1988). The Principles of Marketing: A Guide for Museums. West Sussex, UK: Association of Independent Museums.

Caldwell, N. (2000), "The Emergence of Museum Brands," International Journal of Arts Management, 2(.3), 28-34.

Chiou, Wen-Bin, Wan, C. \& Lee, H. (2008). "Virtual Experience vs. Brochures in the Advertisement of Scenic Spots: How Cognitive Preferences and Order Effects Influence Advertising Effects on Consumers," Tourism Management, 29, 16-150.

Chung, Te-Lin, Marcketti, S. \& Fiore, A. (2014), "Use of Social Networking Services for Marketing Art Museums," Museum Management and Curatorship, 29(2), 188-205.

Falk, J. \& Dierking, L. (1992)... The Museum Experience. Washington, D.C: Whalesback Books. 
Fletcher, A. \& Lee, M. (2012), “Current Social Media Uses and Evaluations in American Museums,” Museum Management and Curatorship, 27(5), 505 -521.

Foster, R. (1988). "Reconciling Museums and Marketing," Museums Journal, 88(3), 127-130.

Gofman, A., Moskowitz, H. \& Mets, T. (2011) "Marketing Museums and Exhibitions: What Drives the Interest of Young People," Journal of Hospitality Marketing \& Management 10, 601-618.

Hausmann, A. (2012) "The Importance of Word of Mouth for Museums: An Analytical Framework," International Journal of Arts Management, 14(3), 32-44.

Jansen, B., Sobel, M. \& Chowdury, A. (2009). "Twitter Power: Tweets as Electronic Word of Mouth," Journal of the American Society for Information Science and Technology, 60(11), 2169-2188.

Kirezli, O. (2011). "Museum Marketing: Shift from Traditional to Experiential Marketing," International Journal of Management Cases, 13, 173-184.

Kotler, N., \& Kotler, P. (2014). "Can Museums be All Things to All People? Missions, Goals, and Marketing's Role," Museum Management and Curatorship, 18(3), 271-287

Kotler, N., Kotler. \& Kotler, W. (2008). Museum Marketing and Strategy: Designing Missions, Building Audiences, Generating Revenue and Resources 2nd Edition. Jossey-Bass: USA.

Liew, W. \& Loh, M. (2007). "E-Marketing, Communications and the International Tourist." In Museum Marketing; competing in the Global Marketplace, edited by Ruth Rentschler and Anne-Marie Hede, 38-47, Oxford, UK: Elsevier.

Lindsay, A. (2013), "VirtualTourist: Embracing Our Audience through Public History Web," The Public Historian, $35(1), 67-86$.

Lumb, A., Gates, A., \& Nelson, A. (2009). Creating Bonds: Successful Marketing in Museums: A Collection of Essays. Edinburgh, UK: MuseumEtc. Marketing Exhibitions: Will They Come (Washington, DC: Smithsonian Institution, 2003), 3.

Marty, P. (2007), "Museum Websites and Museum Visitors: Before and After the Museum Visit," Museum Management and Curatorship, 22(4), 337-360.

McLean, F. (1994) "Services Marketing: The Case of Museums," The Service Industries Journal, 14(2). $190-203$.

McLean, F. (1993), "Marketing in Museums; A Contextual Analysis," Museum Management and Curatorship, 12(1), 11-27.

Miller, R. \& Lammas, N. (2010), "Social Media and its Implications for Viral Marketing." Asia Pacific Public Relations Journal, 11, 1-9.

New York Hotels, Things to Do, Tours, Events \& More | NY State Travel," I LOVE NEW YORK, accessed September 30, $2014 \mathrm{http}: / /$ www.iloveny.com/.

New York State Museum, "Directors Office,” New York State Museum, https://www.nysm.nysed.gov/staff/ index.cfm?categoryID=1 (accessed July 18, 2014);

New York State Museum Charter (http://www.nysm.nysed.gov/charter/ ).

Trends Watch 2012 (American Association of Museums, 2012), 6, http://www.aam-us.org/docs/center-for-thefuture-of-museums/2012_trends_watch_final.pdf?sfvrsn=0 (accessed June 3, 2014).

Stevens, G. \& Luke, W. (2013). A Life in Museums: Managing Your Museum Career, Washington, DC: American Alliance of Museums Press.

Status of NYS Museums | MANY,” accessed September 30, 2014, http://www.manyonline.org/advocacy/status-nysmuseums.

Subramani, M. \& Rajagopalan, B. (2003). "Knowledge-Sharing and Influence in Online Social Networks via Viral Marketing." Communications of the ACM, 46(12), 300-307.

Yucelt, U. (2000), "Marketing Museums; an Empirical Investigation among Museum Visitors," Journal of Nonprofit \& Public Sector Marketing, 8(3), 3-13. 